\title{
Analysis and update of the human solute carrier (SLC) gene superfamily
}

Lei He,' Konstandinos Vasiliou² and Daniel W. Nebert ${ }^{3 *}$

'Massachusetts General Hospital Cancer Center and Harvard Medical School, Boston, MA 02114, USA
${ }^{2}$ Molecular Toxicology and Environmental Health Sciences Program, Department of Pharmaceutical Sciences, University of Colorado
Health Sciences Center, Denver, CO 80262, USA
${ }^{3}$ Department of Environmental Health and Center for Environmental Genetics (CEG), University of Cincinnati Medical Center,
Cincinnati, OH 45267-0056, USA
*Correspondence to: Tel: +1 513558 4347; Fax: +1 513558 3562; E-mail: dan.nebert@uc.edu

Date received 2nd October, 2008

\begin{abstract}
The solute-carrier gene (SLC) superfamily encodes membrane-bound transporters. The SLC superfamily comprises 55 gene families having at least 362 putatively functional protein-coding genes. The gene products include passive transporters, symporters and antiporters, located in all cellular and organelle membranes, except, perhaps, the nuclear membrane. Transport substrates include amino acids and oligopeptides, glucose and other sugars, inorganic cations and anions $\left(\mathrm{H}^{+}, \mathrm{HCO}_{3}{ }^{-}, \mathrm{Cl}^{-}, \mathrm{Na}^{+}, \mathrm{K}^{+}, \mathrm{Ca}^{2+}, \mathrm{Mg}^{2+}, \mathrm{PO}_{4}{ }^{3-}, \mathrm{HPO}_{4}{ }^{2-}, \mathrm{H}_{2} \mathrm{PO}_{4}{ }^{-}\right.$, $\mathrm{SO}_{4}{ }^{2-}, \mathrm{C}_{2} \mathrm{O}_{4}{ }^{2-}, \mathrm{OH}^{-}, \mathrm{CO}_{3}{ }^{2-}$ ), bile salts, carboxylate and other organic anions, acetyl coenzyme $\mathrm{A}$, essential metals, biogenic amines, neurotransmitters, vitamins, fatty acids and lipids, nucleosides, ammonium, choline, thyroid hormone and urea. Contrary to gene nomenclature commonly assigned on the basis of evolutionary divergence (http://www.genenames.org/), the SLC gene superfamily has been named based largely on transporter function by proteins having multiple transmembrane domains. Whereas all the transporters exist for endogenous substrates, it is likely that drugs, non-essential metals and many other environmental toxicants are able to 'hitch-hike' on one or another of these transporters, thereby enabling these moieties to enter (or leave) the cell. Understanding and characterising the functions of these transporters is relevant to medicine, genetics, developmental biology, pharmacology and cancer chemotherapy.
\end{abstract}

Keywords: human genome, transporters, solute carrier gene superfamily, uncoupling proteins, mitochondrial proton carriers, evolutionary genomics

\section{Introduction}

The period between the 1980s and the early 1990s might be considered the era of 'the cloning of genes encoding enzymes and transcription factors', whereas that between the early 1990s and the present day could be regarded as focusing on 'the cloning of genes coding for transporters'. One conceivable reason for the earlier spotlight on many of the enzymes and transcription factors is that those gene products were more abundant and/or could be more easily isolated and antibodies generated against them (compared with transporters).
Transporters are embedded within membranes and generally have multiple transmembrane domains. Another reason might be that the mRNA transcripts for enzymes are usually shorter than those for transporters, and early reverse transcription activities starting at the $3^{\prime}$ end were tedious and less efficient, meaning that longer mRNA transcripts were often unsuccessful.

Proteins with transport functions (http://www. $\mathrm{tcdb}$.org/tcdb/) can roughly be divided into three categories: ATP-powered pumps, ion channels and transporters. ATP-binding cassette (ABC) pumps 
and other ATP-binding pumps use energy released by ATP hydrolysis to move substrates across membranes and out of cells or into cellular vesicles against their electrochemical gradient. These pumps have two states - open and closed. By contrast, ion channels in most cases exist in the closed state. Substrates (ions or water) are transferred down their electrochemical gradient at extremely high efficiency (up to $10^{8} \mathrm{~s}^{-1}$ ). There are $49 A B C$-related functional genes in the human genome (including the genes encoding the cystic fibrosis transmembrane conductance regulator $[C F T R]$ and the transporter associated with antigen processing $[T A P] 1$ and TAP2). Aquaporins (AQPs) are water-channel proteins, encoded by each of $13 A Q P$ functional genes in the human genome (http://www.genenames.org/).

Transporters facilitate the movement of a specific substrate - either with or against its concentration gradient. It is generally believed that conformational change of the transporter protein is important in this transfer process. Transporters move molecules at only about $10^{2}$ to $10^{4} \mathrm{~s}^{-1}$, a rate considerably slower than that associated with channel proteins. Many of these transporters belong to the solutecarrier (SLC) gene superfamily - and include passive transporters, symporters and antiporters, as well as mitochondrial and vesicular transporters. Passive transporters (or uniporters or facilitative transporters) transport one molecule at a time down a concentration gradient. By contrast, active transporters (or co-transporters) couple the movement of one type of ion or molecule against its concentration gradient, to the movement of another ion or molecule down its concentration gradient. (Like ATP pumps, co-transporters mediate coupled reactions in which an energetically unfavourable reaction is coupled to an energetically favourable reaction.) When the transported molecule or ion and the co-transported molecule or ion move in the same direction across a membrane, the transporter is called a symporter; when they move in opposite directions, the transporter is called an antiporter (or exchanger). If the intracellular net charge following transport becomes negative, the process is termed electronegative; if the intracellular net charge becomes positive, the process is called electropositive; if the resulting intracellular net charge remains unchanged, the process is termed electroneutral.

Genes from all these categories are ancient, having members present in most, if not all, prokaryotes, as well as all eukaryotes. Transporters in eukaryotic cells move ions and other molecules across all cellular membranes (cell surface, mitochondrial, endoplasmic reticulum, Golgi and other vesicles), with the possible exception of nuclear membranes (which have pores). The portion of the cell exposed to the lumen is called its apical surface; the rest of the cell (ie its sides and base) make up the basolateral surface. Movement of ions or other molecules into the cell is called influx; movement of ions or other molecules out of the cell is termed efflux.

\section{SLC gene superfamily}

Although several specific families within the SLC superfamily have been reviewed during the past year or two, an overview of the entire gene superfamily has not been attempted since Hediger's publication $^{1}$ and the special 2004 issue of Pflugers Archives, which was devoted entirely to most of the SLC gene families. Such an update at the present time is deemed important because the number of genes now known to be in the SLC superfamily has changed considerably since then (http://www. tcdb.org/hgnc_explore2.php?stem=SLC).

Currently, there are 55 families in the human SLC gene superfamily, with a total of at least 362 putatively functional protein-coding genes. At least 20-25 per cent amino acid sequence identity (most of which occurs in the consensus domain) is shared by member proteins belonging to the same SLC gene family. Table 1 includes the Pfam number (http://pfam.sanger.ac.uk/), consensus sequence (or domain) and GenBank accession number for the first member of the 55 genes/gene products. Note that the SLC35, SLCO1, SLCO2 and SLCO4 families contain two or more subfamilies, whereas the remaining 51 families have no subfamilies (Table 1). In most families where more than one member is present, the first member was 
Table I. Human SLC gene superfamily, including description of the gene products

\begin{tabular}{|c|c|c|c|c|c|}
\hline $\begin{array}{l}\text { Protein } \\
\text { family }\end{array}$ & Description & $\begin{array}{l}\text { Number of } \\
\text { members }\end{array}$ & Pfam & Domain & $\begin{array}{l}\text { GenBank } \\
\text { accession } \\
\text { number }\end{array}$ \\
\hline $\mathrm{SLCl}$ & $\begin{array}{l}\text { High-affinity glutamate } \\
\text { and neutral amino acid } \\
\text { transporter family }\end{array}$ & 7 & PF00375 & SDF & NP_004I6I \\
\hline SLC2 & $\begin{array}{l}\text { Facilitative glucose } \\
\text { transporter (GLUT) } \\
\text { family }\end{array}$ & 14; 5 pseudo & PF00083 & Sugar_tr & NP_006507 \\
\hline SLC3 & $\begin{array}{l}\text { Heavy subunits of the } \\
\text { heteromeric amino acid } \\
\text { transporters }\end{array}$ & 2 & PF00I28 & Alpha-amylase & NP_000332 \\
\hline \multirow[t]{2}{*}{ SLC4 } & $\begin{array}{l}\text { Bicarbonate transporter } \\
\text { family }\end{array}$ & 10 & PF07565 & Band_3_cyto & NP_000333 \\
\hline & & & PF00955 & HC03_cotransp & \\
\hline SLC5 & $\begin{array}{l}\mathrm{Na}^{+} / \text {glucose } \\
\text { co-transporter family }\end{array}$ & 12 & PF00474 & SSF & NP_000334 \\
\hline SLC6 & $\begin{array}{l}\mathrm{Na}^{+} \text {- and } \mathrm{Cl}^{-} \text {-dependent } \\
\text { neurotransmitter } \\
\text { symporter family }\end{array}$ & 19; 3 pseudo & PF00209 & SNF & NP_003033 \\
\hline SLC7 & $\begin{array}{l}\text { Cationic amino acid } \\
\text { transporter/glycoprotein- } \\
\text { associated amino acid } \\
\text { transporter family }\end{array}$ & 14; I pseudo & PF00324 & AA_permease & NP_003036 \\
\hline \multirow[t]{2}{*}{ SLC8 } & $\begin{array}{l}\mathrm{Na}^{+} / \mathrm{Ca}^{2+} \text { exchanger } \\
\text { family }\end{array}$ & 3 & PF03I60 & $\mathrm{Na} \_\mathrm{Ca}$ ex & NP_066920 \\
\hline & & & PF0I699 & Calx_eta & \\
\hline SLC9 & $\mathrm{Na}^{+} / \mathrm{H}^{+}$exchanger family & II; 4 pseudo & PF00999 & $\mathrm{Na} \_\mathrm{H} \_$Exchanger & \\
\hline SLCIO & $\begin{array}{l}\mathrm{Na}^{+} / \text {bile salt } \\
\text { co-transporter family }\end{array}$ & 7 & PF0I758 & SBF & NP_003040 \\
\hline SLCII & $\begin{array}{l}\text { Proton-coupled metal ion } \\
\text { transporter family }\end{array}$ & 2 & PF0I566 & Nramp & NP_000569 \\
\hline \multirow[t]{2}{*}{$\mathrm{SLCl} 2$} & $\begin{array}{l}\text { Electroneutral cation } / \mathrm{Cl}^{-} \\
\text {co-transporter family }\end{array}$ & 9 & PF00324 & AA_permease & NP_000329 \\
\hline & & & PF08403 & & \\
\hline $\mathrm{SLCI} 3$ & $\begin{array}{l}\mathrm{Na}^{+} / \mathrm{SO}_{4}{ }^{2-} / \text { carboxylate } \\
\text { co-transporter family }\end{array}$ & 5 & PF00939 & Na_sulph_symp & NP_07I889 \\
\hline $\mathrm{SLCl} 4$ & Urea transporter family & 2 & PF03253 & UT & NP_056949 \\
\hline SLCI5 & $\begin{array}{l}\text { Proton oligopeptide } \\
\text { co-transporter family }\end{array}$ & 4 & PF00854 & PTR2 & NP_005064 \\
\hline
\end{tabular}

Continued 
Table I. Continued

\begin{tabular}{|c|c|c|c|c|c|}
\hline $\begin{array}{l}\text { Protein } \\
\text { family }\end{array}$ & Description & $\begin{array}{l}\text { Number of } \\
\text { members }\end{array}$ & Pfam & Domain & $\begin{array}{l}\text { GenBank } \\
\text { accession } \\
\text { number }\end{array}$ \\
\hline $\mathrm{SLCl} 6$ & $\begin{array}{l}\text { Monocarboxylate } \\
\text { transporter family }\end{array}$ & 14 & PF07690 & MFS_I & NP_003042 \\
\hline SLCI7 & $\begin{array}{l}\text { Vesicular glutamate } \\
\text { transporter family }\end{array}$ & 8 & PF07690 & MFS_I & NP_005065 \\
\hline SLCI8 & $\begin{array}{l}\text { Vesicular amine } \\
\text { transporter family }\end{array}$ & 3 & PF07690 & MFS_I & NP_003044 \\
\hline SLCI9 & $\begin{array}{l}\text { Folate/thiamine } \\
\text { transporter family }\end{array}$ & 3 & PF0I770 & Folate_carrier & NP_919231 \\
\hline SLC20 & $\begin{array}{l}\text { Type-III Na }{ }^{+} / \mathrm{H}_{2} \mathrm{PO}_{4}{ }^{-} \\
\text {co-transporter family }\end{array}$ & 2; I pseudo & PF0I384 & $\mathrm{PH} 04$ & NP_006740 \\
\hline SLC22 & $\begin{array}{l}\text { Organic cation/anion/ } \\
\text { zwitterion transporter } \\
\text { family }\end{array}$ & 23 & PF07690 & MFS_I & NP_003048 \\
\hline SLC23 & $\begin{array}{l}\mathrm{Na}^{+} \text {-dependent ascorbic } \\
\text { acid transporter family }\end{array}$ & 4 & PF00860 & Xan_ur_permease & NP_005838 \\
\hline SLC24 & $\begin{array}{l}\mathrm{Na}^{+} / \mathrm{Ca}^{2+} \text { and } \mathrm{Na}^{+} / \mathrm{K}^{+} \\
\text {exchanger family }\end{array}$ & 6 & PFOI699 & $\mathrm{Na}$ _Ca_ex & NP_0047I8 \\
\hline SLC25 & $\begin{array}{l}\text { Mitochondrial carrier } \\
\text { family }\end{array}$ & 43; 4 pseudo & PF00I53 & Mito_carr & NP_005975 \\
\hline \multirow[t]{2}{*}{ SLC26 } & $\begin{array}{l}\text { Multifunctional anion } \\
\text { exchanger family }\end{array}$ & 11 & PFOI 740 & Sulfate_transp & NP_998778 \\
\hline & & & PF00916 & STAS & \\
\hline SLC27 & $\begin{array}{l}\text { Fatty acid transport } \\
\text { protein family }\end{array}$ & 6 & PF0050I & AMP-binding & NP_940982 \\
\hline \multirow[t]{3}{*}{ SLC28 } & $\begin{array}{l}\mathrm{Na}^{+} \text {-coupled nucleoside } \\
\text { transport family }\end{array}$ & 3 & PF07670 & Gate & NP_004204 \\
\hline & & & PF07662 & Nucleos_tra2_C & \\
\hline & & & PF0I773 & & \\
\hline SLC29 & $\begin{array}{l}\text { Facilitative nucleoside } \\
\text { transporter family }\end{array}$ & 4 & PF0I733 & Nucleoside_tran & NP_001071642 \\
\hline SLC30 & $\mathrm{Zn}^{2+}$ efflux family & 10 & PF0I545 & Cation_efflux & NP_067017 \\
\hline SLC3I & Copper transporter family & 2; I pseudo & PF04I45 & Ctr & NP_00I850 \\
\hline SLC32 & $\begin{array}{l}\text { Vesicular inhibitory amino } \\
\text { acid transporter family }\end{array}$ & 1 & PF0I490 & Aa_trans & NP_542119 \\
\hline SLC33 & $\begin{array}{l}\text { Acetyl coenzyme A } \\
\text { transporter family }\end{array}$ & 1 & IPR004752 & $2 \mathrm{~A} 0 \mathrm{I} 25$ & NP_004724 \\
\hline
\end{tabular}


Table I. Continued

\begin{tabular}{|c|c|c|c|c|c|}
\hline $\begin{array}{l}\text { Protein } \\
\text { family }\end{array}$ & Description & $\begin{array}{l}\text { Number of } \\
\text { members }\end{array}$ & Pfam & Domain & $\begin{array}{l}\text { GenBank } \\
\text { accession } \\
\text { number }\end{array}$ \\
\hline SLC34 & $\begin{array}{l}\text { Type-II Na }{ }^{+} / \mathrm{HPO}_{4}{ }^{2-} \\
\text { co-transporter family }\end{array}$ & 3 & PF02690 & $\mathrm{Na}$ _Pi_cotrans & NP_003043 \\
\hline $\begin{array}{l}\text { SLC35 } \\
(A, B, C, D, E, F)\end{array}$ & $\begin{array}{l}\text { Nucleoside-sugar } \\
\text { transporter family }\end{array}$ & 23 & PF04I42 & Nuc_sug_transp & NP_006407 \\
\hline SLC36 & $\begin{array}{l}\text { Proton-coupled amino } \\
\text { acid transporter family }\end{array}$ & 4 & PF0I490 & Aa_trans & NP_5I0968 \\
\hline SLC37 & $\begin{array}{l}\text { Sugar- } \mathrm{PO}_{4}{ }^{3-} / \mathrm{PO}_{4}{ }^{3-} \\
\text { exchanger family }\end{array}$ & 4 & PF07690 & MFS_I & NP_061837 \\
\hline SLC38 & $\begin{array}{l}\text { System A \& N, } \\
\mathrm{Na}^{+} \text {-coupled neutral } \\
\text { amino acid transporter } \\
\text { family }\end{array}$ & II & PF0I490 & Aa_trans & NP_109599 \\
\hline SLC39 & $\begin{array}{l}\text { Metal }\left(\mathrm{M}^{2+}\right) \text { ion } \\
\text { transporter family }\end{array}$ & 14 & PF02535 & Zip & NP_055252 \\
\hline SLC40 & $\begin{array}{l}\text { Basolateral iron } \\
\text { transporter family }\end{array}$ & I & PF06963 & FPNI & NP_055400 \\
\hline SLC4I & $\begin{array}{l}\text { MgtE-like } \mathrm{Mg}^{2+} \\
\text { transporter family }\end{array}$ & 3 & PFOI 769 & $\mathrm{MgtE}$ & NP_776253 \\
\hline SLC42 & $\begin{array}{l}\text { Rh-associated } \\
\text { glycoproteins; } \mathrm{NH}_{4}{ }^{+} \\
\text {transporter family }\end{array}$ & 3 & & & \\
\hline SLC43 & $\begin{array}{l}\mathrm{Na}^{+} \text {-independent } \\
\text { system-L-like amino acid } \\
\text { transporter family }\end{array}$ & 3 & & & NP_003618 \\
\hline SLC44 & $\begin{array}{l}\text { Choline-like } \\
\text { transmembrane } \\
\text { transporter activity }\end{array}$ & 5 & PF045I5 & DUF580 & NP_536856 \\
\hline SLC45 & $\begin{array}{l}\text { Putative sugar } / \mathrm{H}^{+} \\
\text {symporter activity }\end{array}$ & 4 & PF07690 & MFS_I & NP_001073866 \\
\hline SLC46 & $\begin{array}{l}\text { Folic acid transporter } \\
\text { (heme-containing) activity }\end{array}$ & 3 & PF07690 & MFS_I & NP_542400 \\
\hline SLC47 & $\begin{array}{l}\text { Polyspecific } \mathrm{H}^{+} \text {/organic } \\
\text { cation exporter }\end{array}$ & 2 & PFOI554 & MatE & NP_0607I2 \\
\hline \multirow[t]{2}{*}{$\begin{array}{l}\text { SLCOI } \\
(A, B, C)\end{array}$} & $\begin{array}{l}\text { Drug, organic anion } \\
\text { transporter family }\end{array}$ & 4 & PF07648 & OATP & NP_602307 \\
\hline & & & PF03I37 & & \\
\hline $\begin{array}{l}\text { SLCO2 } \\
(A, B)\end{array}$ & $\begin{array}{l}\text { Prostaglandin and steroid } \\
\text { sulphate transporter family }\end{array}$ & 2 & PF07648 & OATP & NP_00562I \\
\hline
\end{tabular}

Continued 
Table I. Continued

\begin{tabular}{|c|c|c|c|c|c|}
\hline $\begin{array}{l}\text { Protein } \\
\text { family }\end{array}$ & Description & $\begin{array}{l}\text { Number of } \\
\text { members }\end{array}$ & Pfam & Domain & $\begin{array}{l}\text { GenBank } \\
\text { accession } \\
\text { number }\end{array}$ \\
\hline & & & PF03। 37 & & \\
\hline \multirow[t]{2}{*}{ SLCO3 } & $\begin{array}{l}\text { Drug and organic anion } \\
\text { transporter activity }\end{array}$ & I & PF07648 & OATP & NP_037404 \\
\hline & & & PF03। 37 & KAzal_2 & \\
\hline \multirow[t]{2}{*}{$\begin{array}{l}\text { SLCO4 } \\
(A, C)\end{array}$} & $\begin{array}{l}\text { Thyroid hormone } \\
\text { transmembrane } \\
\text { transporter activity }\end{array}$ & 2 & PF07648 & OATP & NP_057438 \\
\hline & & & PF03। 37 & & \\
\hline \multirow[t]{2}{*}{ SLCO5 } & $\begin{array}{l}\text { Drug and organic anion } \\
\text { transporter activity }\end{array}$ & I & PF07648 & OATP & NP_II 2220 \\
\hline & & & PF03। 37 & & \\
\hline \multirow[t]{2}{*}{ SLCO6 } & $\begin{array}{l}\text { Drug and organic anion } \\
\text { transporter activity }\end{array}$ & I & PF07648 & OATP & NP_775759 \\
\hline & & & PF03। 37 & Kazal_2 & \\
\hline UCPI & $\begin{array}{l}\text { Oxidative } \\
\text { phosphorylation } \\
\text { uncoupling activity } \\
\text { (proton carrier) }\end{array}$ & I & PF00I53 & Mito_carr & NP_068605 \\
\hline UCP2 & $\begin{array}{l}\text { Oxidative } \\
\text { phosphorylation } \\
\text { uncoupling activity } \\
\text { (proton carrier) }\end{array}$ & I & PF00I53 & Mito_carr & NP_003346 \\
\hline UCP3 & $\begin{array}{l}\text { Oxidative } \\
\text { phosphorylation } \\
\text { uncoupling activity } \\
\text { (proton carrier) }\end{array}$ & I & PF00I53 & Mito_carr & NP_003347 \\
\hline
\end{tabular}

The numbers of documented pseudogenes ('pseudo'), to date, are noted in the 'Number of members' column; these numbers are likely to be gross underestimates, however, because if one does a BLAST search with each exon, numerous 'bits and pieces' of the gene plus detritus exons will probably be discovered. ${ }^{2}$

chosen to represent that entire family for the global amino acid alignment of the 55 proteins to generate a nearest-neighbour-joining (NNJ) dendrogram (Figure 1).

What had originally been named the 'SLC21 (organic-anion transporting) family' has now been changed to six highly divergent SLCO families. Also, the SLC42 family has its genes named RHAG, RHBG and RHCG, because they were first characterised as members of the blood $\mathrm{Rh}$ factor antigen family (Table 1).

\section{Evolution of the SLC genes}

We examined the SLC superfamily by the NNJ method (Figure 1); we included two functionally unrelated 'outlier' genes (SOD1, encoding a soluble protein, and CYP1A1, encoding a membrane-bound protein) and two 'internal controls' within the same subfamily (SLC39A2 and SLC39A3, together with SLC39A1). SOD1 and CYP1A1 appeared to be 'evolutionarily related' to SLC7 and SLC3, respectively (Figure 1). Thus, 


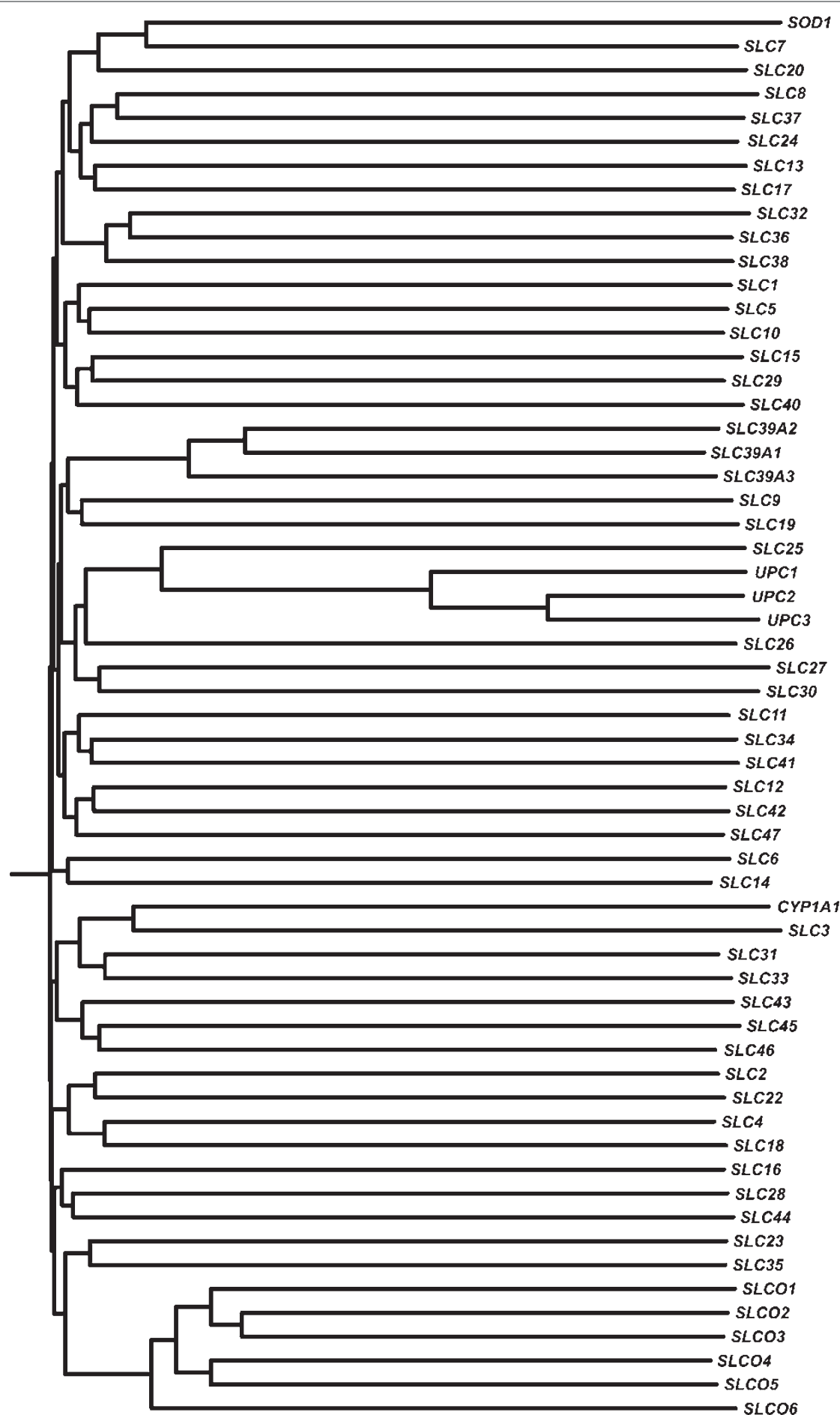

Figure I. Dendrogram of a representative member of each of the 55 human SLC gene families, developed using Clustal W software, to test for evolutionary readiness. To avoid clutter, we have selected only the first member of each family, although most families have two or more members. We also added two unrelated 'outlier' genes (SODI and CYPIAI) and two additional members of the SLC39 family (SLC39A2 and SLC39A3) as 'internal controls'. This nearest neighbour-joining (NNJ) method uses only global alignments of the entire protein sequences. In this case, although the NNJ method appears to gives various branches of different lengths, reflecting the presumed time since evolutionary divergence of the various branches of the gene tree, this tree is largely an artefact because the superfamily has mainly been pulled together by nomenclature experts who based this superfamily on function, rather than evolutionary divergence (see text). 
whereas the three SLC39 family members are clustered, the unrelated 'outliers' did not fall outside the superfamily tree (as they should). From these findings, we conclude that - although the NNJ method of analysis suggests an evolutionary tree one cannot detect sufficient evolutionary relatedness for the vast majority of the 55 SLC families making up this superfamily.

There are two clusters of gene families, however, that do show evolutionary relatedness (Figure 1). One is the mitochondrial-transport SLC25 family (of 43 members) clustered together with the three UCP families. This cluster is undoubtedly real because all members are concerned with transport across mitochondrial membranes. The other cluster is the group of six SLCO families. This is intriguing, especially because (vide infra) the substrates are fairly diverse (organic anions and drugs, prostaglandins, lipids and thyroid hormone).

Beyond those two clusters, we see no other statistically significant evolutionary relatedness. Therefore, with the exception of these two clusters, the remainder of the SLC gene families will be discussed on the basis of their common substrates. Many genes in the SLC superfamily are involved in paediatric inherited disorders and other human diseases (see Bergeron et al. ${ }^{3}$ and http://www.ncbi. nlm.nih.gov/sites/entrez? $\mathrm{db}=\mathrm{omim})$. In addition, the functional properties of each family are often summarised on the basis of just a few members that have been thoroughly characterised. If that family has, say, 12 or 23 members, we should keep in mind that it is possible that some of the other members yet to be characterised will not adhere strictly to that specific moniker.

\section{Inorganic cation/anion transport}

Teleologically, one might argue that inorganic cation and anion transport would be, in evolutionary terms, among the oldest transport functions. Eight families comprise the group that transports exclusively inorganic cations and anions across membranes (Table 1): SLC4, with ten members, plays a pivotal role in mediating $\mathrm{Na}^{+}-$and/or $\mathrm{Cl}^{-}$-dependent transport of basic anions (eg
$\left.\mathrm{HCO}_{3}^{-}, \mathrm{CO}_{3}{ }^{2-}\right)$ in various tissues and cell types (in addition to $\mathrm{pH}$ regulation, specific members of this family also contribute to vectorial transepithelial base transport in several organ systems, including the kidney, pancreas and eye); ${ }^{4}$ SLC8, with three members, is a group of $\mathrm{Na}^{+} / \mathrm{Ca}^{2+}$ exchangers (SLC8A1 is known to exchange three extracellular $\mathrm{Na}^{+}$ions for one intracellular $\mathrm{Ca}^{2+}$ ion and to be involved in cardiac contractility); ${ }^{5}$ SLC9, with 11 members, comprises $\mathrm{Na}^{+} / \mathrm{H}^{+}$exchanger proteins involved in the electroneutral exchange of $\mathrm{Na}^{+}$and $\mathrm{H}^{+}{ }^{6}$ SLC12, with nine members, functions as a Na${ }^{+}, \mathrm{K}^{+}$and $\mathrm{Cl}^{-}$ion electroneutral symporter; ${ }^{7,8}$ SLC34, with three members, is an important type II $\mathrm{Na}^{+} /\left(\mathrm{HPO}_{4}\right)^{2-}$ symporter; ${ }^{9,10}$ SLC20, with two members, originally identified as a viral receptor, ${ }^{11}$ functions as a type III $\mathrm{Na}^{+} /$ $\left(\mathrm{H}_{2} \mathrm{PO}_{4}\right)^{-}$symporter; ${ }^{10,11}$ SLC24, with six members, is a group of $\mathrm{Na}^{+} / \mathrm{Ca}^{2+}$ or $\mathrm{Na}^{+} / \mathrm{K}^{+}$ exchangers; ${ }^{12}$ and SLC26, with 11 members, is the transepithelial multifunctional anion (eg sulfate, oxalate, $\mathrm{HCO}_{3}^{-}, \mathrm{Cl}^{-}$) exchanger family, ${ }^{13,14}$ also important in sound amplification in the cochlea. ${ }^{15}$

\section{Amino acid and oligopeptide transport}

Eight families are involved as transporters of amino acids and/or oligopeptides (Table 1): SLC1, with seven members, transports high-affinity glutamate and neutral amino acids; ${ }^{3,16}$ SLC3, with two members, encodes transporters of heavy subunits of heteromeric amino acids. ${ }^{3,17}$ The SLC3 family (along with other amino acid carrier SLC1, SLC6 and SCL7 families, plus the glucose carrier SLC2 and SLC5 families) is regarded as a collection of transporters that function mainly in 'epithelialderived' cells; ${ }^{3}$ SLC7, with 14 members, represents cationic amino acid/glycoprotein transporters; 3,18 SLC15, with four members, represents a family of proton-oligopeptide symporters; ${ }^{19,20}$ SLC17, with eight members, is involved in diverse processes ranging from the vesicular storage of the neurotransmitter glutamate to the degradation and metabolism of glycoproteins; ${ }^{21}$ SLC32, with one member only, transports amino acids across vesicle 
membranes; ${ }^{22}$ SLC36, with four members (a mutation in the SLC36A1 gene was recently found to be associated with champagne dilution coat colour in horses ${ }^{23}$ ), is involved in proton-coupled amino acid transport; ${ }^{24}$ SLC38, with 11 members, functions as a sodium-coupled neutral amino-acid transporter; ${ }^{25}$ and SLC43, with three members, represents the sodium-independent system-L-like (ie mediating the movement of bulky neutral amino acids across cell membranes) amino acid transporter family. ${ }^{1,26}$ It is worth noting that the SLC32, SLC36 and SLC38 families do appear to be evolutionarily related (Figure 1). SLC16 and SLC22 also transport amino acids, among other substrates, and are described later.

\section{Transport of glucose and other sugars}

Four families function as sugar transporters (Table 1): SLC2, with 14 members, is the well-studied facilitative glucose transporter (GLUT) family; ${ }^{2,27}$ SLC5, with 12 members, functions as a $\mathrm{Na}^{+} /$glucose symporter; ${ }^{2,28}$ SLC37, with four members, is a group of sugar $-\mathrm{PO}_{4}^{-} / \mathrm{PO}_{4}^{-}$exchangers, with glucose-6$\mathrm{PO}_{4}^{-}$transporter-1 being the most well characterised; ${ }^{29}$ and SLC45, with four members, appears to function as a sugar $/ \mathrm{H}^{+}$symporter. The SLC45A1 gene is located at $1 \mathrm{p} 36.23 .^{30}$ SLC 45A2, associated with skin pigmentation and protection against malignant melanoma, ${ }^{31}$ is located at $5 \mathrm{p} 13.3$. SLC45A3, located at 1q32.1, is, curiously, one of several genes that have been found to be involved in recurrent gene rearrangements in prostate cancer. $^{32}$ SLC45A4 ${ }^{33}$ was mapped to $8 \mathrm{q} 24.3$ (http://www.genenames.org/).

\section{Transport of bile salts and organic anions}

Four families participate as transporters of bile salts and organic anions (Table 1): SLC10, with seven members, is involved in bile acid transport; ${ }^{34}$ SLC13, with five members, is the $\mathrm{Na}^{+}$/sulphate/ selenate/thiosulphate/carboxylate symporter family. The di- and tri-carboxylates include succinate, citrate and alpha-ketoglutarate ${ }^{35}$ SLC16, with 14 members, is involved in the proton-linked transport of monocarboxylate anions (eg lactate, pyruvate and ketone bodies) and aromatic amino acids; ${ }^{36}$ and SLC47, with two members, has so far only been characterised as a polyspecific $\mathrm{H}^{+}$/organic cation exporter. ${ }^{37}$ The SLC47 genes have also been nicknamed 'multidrug and toxicant extrusion-1 and -2' (MATE1 and MATE2). The SLC47A1 and SLC47A2 genes both map to $17 \mathrm{p} 11.2$ (http:// www.genenames.org/. Four of the SLCO families also participate in organic anion transport, and these are separately described later as an evolutionary cluster.

\section{Metal ion transport}

Six SLC families are involved in metal ion transport (Table 1): SLC11, with two members that function as proton-coupled metal ion influx transporters, also known as the 'natural resistance-associated macrophage protein' (NRAMP) homologues; ${ }^{38}$ SLC30, with ten members, is involved in $\mathrm{Zn}^{2+}$ efflux; ${ }^{39,40}$ SLC31, with two members, is a copper influx transporter family; ${ }^{41}$ SLC39, with 14 members, functions in the influx of essential metals such as $\mathrm{Zn}^{2+}, \mathrm{Fe}^{2+}$, $\mathrm{Cu}^{2+}$ and $\mathrm{Mn}^{2+}, 40,42$ although non-essential toxic metals such as $\mathrm{Cd}^{2+}, \mathrm{Pb}^{2+}$ and $\mathrm{Hg}^{2+}$ can 'hijack' at least two of these transporters; ${ }^{43,44}$ SLC40, with one member only, is a basolateral iron transporter; ${ }^{45}$ and SLC41, with three members, is the 'MgtE-like' magnesium transporter family, which has been characterised principally in prokaryotes (also found in yeast, worm and fly), while their physiological role in eukaryotes remains unclear. ${ }^{46}$

\section{Transport of urea, neurotransmitters and biogenic amines, ammonium and choline}

Five families participate in the transport of these molecules (Table 1): SLC6, with 19 members, represents $\mathrm{Na}^{+}$and $\mathrm{Cl}^{-}$ion-dependent neurotransmitter (gamma-aminobutyric acid [GABA], serotonin, dopamine and norepinephrine) transporters, ${ }^{3,47}$ having relatives even in prokaryotes; ${ }^{48}$ SLC14, with 
two members, is involved in the transport of urea; ${ }^{49}$ SLC18, with three members, transports acetylcholine (by the vesicular acetylcholine transporter SLC18A3) and biogenic amines (by the vesicular monoamine transporters SLC18A1 and SLC18A2) into secretory vesicles, which are then discharged into the extracellular space by exocytosis; ${ }^{50}$ SLC22, with 23 members, is highly conserved in the fly and worm, functions in endogenous organic cation/ anion/zwitterion (eg carnitine, betaines, amino acids) transport and thus is very important in drug transporter functions; ${ }^{51}$ SLC42, with three members ${ }^{52}$ that appear to be involved in $\mathrm{NH}_{4}{ }^{+}$ transport (whereas their gene names are RHAG, RHBG and RHCG); and SLC44, with five members and homologues in yeast, fly and worm, appears to be involved in choline transport. ${ }^{53}$

\section{Transport of vitamins and cofactors}

Four families participate in vitamin or cofactor transport (Table 1): SLC19, with three members, transports folate and thiamine, energised by a transmembrane $\mathrm{H}^{+} / \mathrm{OH}^{-}$gradient; ${ }^{54}$ SLC23, with four members, transports ascorbic acid; ${ }^{55}$ SLC33, with a single member, is an acetyl coenzyme A transporter, which serves as a substrate of acetyltransferases that modify the sialyl residues of gangliosides and glycoproteins; ${ }^{56}$ SLC46, with three members, is involved in proton-coupled folic acid transport. Homozygous mutations in the SLC46A1 gene, located at $17 \mathrm{q} 11.2$, are associated with hereditary folate malabsorption. ${ }^{57}$ SLC $46 A 2^{58}$ maps to $9 \mathrm{q} 32$, and SLC46A3 $3^{33,59}$ to $13 \mathrm{q} 12.3$ (http://www.genenames.org/).

\section{Nucleoside/nucleotide transport}

Three families carry out the transport of nucleosides and nucleotides (Table 1): SLC28, with three members, functions in $\mathrm{Na}^{+}$-coupled nucleoside transport and thus is a potentially important pharmacological target; ${ }^{60}$ SLC29, with four members, mediates (along with the SLC28 transporters) uptake of natural nucleosides (among them adenosine) - these members are major routes of entry for a variety of nucleoside analogues used in anticancer and antiviral therapies; ${ }^{61}$ SLC35, with 23 members, transports nucleotide sugars (pooled in the cytosol) into the lumen of the Golgi apparatus and endoplasmic reticulum, wherein occurs most of the synthesis of glycoconjugates. ${ }^{62}$

\section{Transport of fatty acids, prostaglandins and steroid sulphates}

Two SLC families are involved in these functions (Table 1): SLC27, with six members, participates in the transport of long-chain fatty acids; ${ }^{63}$ and SLCO2, with two members (detailed below), functions in prostaglandin and steroid sulphate transport.

\section{SLCO gene families}

The six SLCO gene families represent an evolutionary cluster (Figure 1); four of the families are involved in organic anion-transporting polypeptides (OATPs), which include 14 transmembrane-domain glycoproteins expressed ${ }^{64}$ in various epithelial cells (Table 1): SLCO1, with four members, is involved in drug transport; SLCO3, with a single member, transports unknown organic anions; SLCO5 and SLCO6, both families having a single member, also transport unknown organic anions and are believed to be important in drug transport, whereas SLCO2, with two members, functions in the transport of prostaglandins ${ }^{65}$ and steroid sulphates. ${ }^{66}$ SLCO4, with two members, functions in the transport of thyroid hormone. ${ }^{67}$ Most of the SLCO proteins have not yet been well characterised.

\section{Transport across mitochondrial membranes}

The four gene families involved in mitochondrial transport also represent an evolutionary cluster (Figure 1): SLC25, with 43 members (the largest of all SLC families), is known to comprise the 'mitochondrial carriers', shuttling a variety of metabolites across the mitochondrial inner membrane; ${ }^{68}$ and UCP1, ${ }^{69}$ $\mathrm{UCP}^{70,71}$ and $\mathrm{UCP}^{70}$ (located at chromosomes 4q28-q31, 11q13 and 11q13.4, respectively) function 
as ancient uncoupling proteins, or proton pumps involved in mitochondrial energetics (Table 1).

\section{Conclusions}

The SLC gene superfamily comprises 55 families, totalling at last 362 putatively functional proteincoding genes that encode multiple transmembrane transporters. Whereas all the transporters undoubtedly have endogenous substrates, drugs, non-essential metals and many other environmental toxicants in all likelihood are able to 'hitch-hike' on one or another of these transporters, thereby being able to enter (or leave) the cell. Understanding and characterising the functions of all these transporters should be relevant to medicine, genetics, pharmacology and cancer chemotherapy. Because more than half of these genes remain to be characterised, this field seems ripe - perhaps especially for young investigators who wish to choose a research topic with little or no competition at the present time.

\section{Acknowledgments}

We thank our colleagues, especially David R. Nelson, for valuable discussions and a critical reading of this manuscript. The writing of this review paper was funded, in part, by NIH grant P30 ES06096 (D.W.N.).

NOTE ADDED IN PROOF: The SLC22A12 gene is known to encode urate transporter-1. The very recent finding of an association of mutations in the SLC2A9 gene from dogs exhibiting hyper uricosuria and hyperuricaemia* underscores the importance of SLC289 as an additional uric acid transporter in mammals, which in all likelihood include humans.

*Bannasch, D., Safra, N., Young, A., Karmi, N., Schaible, R.S. and Ling, G.V. (2008), 'Mutations in the SLC289 gene cause hyperuricosuria and hyperuricemia in the dog', PLoS Genet. 30 November; e1000246.

\section{References}

1. Hediger, M.A., Romero, M.F, Peng, J.B., Rolfs, A., Takanaga, H. and Bruford, E.A. (2004), 'The ABCs of solute carriers: Physiological, pathological and therapeutic implications of human membrane transport proteins. Introduction', Pfluegers Arch. Vol. 447, pp. 465-468.

2. Nelson, D.R., Zeldin, D.C., Hoffman, S.M., Maltais, L.J., Wain, H.M. and Nebert, D.W. (2004), 'Comparison of cytochrome P450 (CYP) genes from the mouse and human genomes, including nomenclature recommendations for genes, pseudogenes and alternative-splice variants', Pharmacogenetics Vol. 14, pp. 1-18.

3. Bergeron, M.J., Simonin, A., Burzle, M. and Hediger, M.A. (2008), 'Inherited epithelial transporter disorders - an overview', J. Inherit. Metab. Dis. Vol. 31, pp. 178-187.
4. Pushkin, A. and Kurtz, I. (2006), 'SLC4 base $\left[\mathrm{HCO}_{3}^{-},\left(\mathrm{CO}_{3}\right)^{2-}\right]$ transporters: Classification, function, structure, genetic diseases, and knockout models', Am. J. Physiol. Renal Physiol. Vol. 290, pp. F580-F599.

5. Quednau, B.D., Nicoll, D.A. and Philipson, K.D. (2004), 'The sodium/ calcium exchanger family - SLC8', Pflugers Arch. Vol. 447, pp. 543-548.

6. Orlowski, J. and Grinstein, S. (2004), 'Diversity of the mammalian sodium/proton exchanger SLC9 gene family', Pflugers Arch. Vol. 447, pp. $549-565$.

7. Hebert, S.C., Mount, D.B. and Gamba, G. (2004), 'Molecular physiology of cation-coupled $\mathrm{Cl}^{-}$cotransport: The SLC12 family', Pflugers Arch. Vol. 447, pp. 580-593.

8. Peng, J.B. and Warnock, D.G. (2007), 'WNK4-mediated regulation of renal ion transport proteins', Am. J. Physiol. Renal Physiol. Vol. 293, pp. F961-F973.

9. Forster, I.C., Hernando, N., Biber, J. and Murer, H. (2006), 'Proximal tubular handling of phosphate: A molecular perspective', Kidney Int. Vol. 70, pp. 1548-1559.

10. Virkki, L.V., Biber, J., Murer, H. and Forster, I.C. (2007), 'Phosphate transporters: A tale of two solute carrier families', Am. J. Physiol. Renal Physiol. Vol. 293, pp. F643-F654.

11. Collins, J.F, Bai, L. and Ghishan, F.K. (2004), 'The SLC20 family of proteins: Dual functions as sodium-phosphate cotransporters and viral receptors', Pflugers Arch. Vol. 447, pp. 647-652.

12. Altimimi, H.F. and Schnetkamp, P.P. (2007), $\mathrm{Na}^{+} / \mathrm{Ca}^{2+}$ and $\mathrm{Na}^{+} / \mathrm{K}^{+}$ exchangers (NCKX): Functional properties and physiological roles', Channels (Austin) Vol. 1, pp. 62-69.

13. Sindic, A., Chang, M.H., Mount, D.B. and Romero, M.F. (2007), 'Renal physiology of SLC26 anion exchangers', Curr. Opin. Nephrol. Hypertens. Vol. 16, pp. 484-490.

14. Dorwart, M.R., Shcheynikov, N., Yang, D. and Muallem, S. (2008), 'The solute carrier 26 family of proteins in epithelial ion transport', Physiology (Bethesda) Vol. 23, pp. 104-114.

15. Ashmore, J. (2008), 'Cochlear outer hair cell motility', Physiol. Rev. Vol. 88 , pp. $173-210$.

16. Torres, G.E. and Amara, S.G. (2007), 'Glutamate and monoamine transporters: New visions of form and function', Curr. Opin. Neurobiol. Vol. 17, pp. 304-312.

17. Palacin, M., Nunes, V., Font-Llitjos, M. et al. (2005), 'The genetics of heteromeric amino acid transporters', Physiology (Bethesda) Vol. 20, pp. 112-124.

18. Closs, E.I., Boissel, J.P., Habermeier, A. and Rotmann, A. (2006), 'Structure and function of cationic amino acid transporters (CATs)', J. Membr. Biol. Vol. 213, pp. 67-77.

19. Daniel, H. and Kottra, G. (2004), 'The proton oligopeptide cotransporter family SLC15 in physiology and pharmacology', Pflugers Arch. Vol. 447, pp. 610-618.

20. Zair, Z.M., Eloranta, J.J., Stieger, B. and Kullak-Ublick, G.A. (2008), 'Pharmacogenetics of OATP (SLC21/SLCO), OAT and OCT (SLC22) and PEPT (SLC15) transporters in the intestine, liver and kidney', Pharmacogenomics Vol. 9, pp. 597-624.

21. Reimer, R.J. and Edwards, R.H. (2004), 'Organic anion transport is the primary function of the SLC17/type I phosphate transporter family', Pflugers Arch. Vol. 447, p. 629-635.

22. Gasnier, B. (2004), 'The SLC32 transporter, a key protein for the synaptic release of inhibitory amino acids', Pflugers Arch. Vol. 447, pp. 756-759.

23. Cook, D., Brooks, S., Bellone, R. and Bailey, E. (2008), 'Missense mutation in exon 2 of SLC36A1 responsible for champagne dilution in horses', PLoS Genet. Vol. 4, p. e1000195.

24. Boll, M., Daniel, H. and Gasnier, B. (2004), 'The SLC36 family: Proton-coupled transporters for the absorption of selected amino acids from extracellular and intracellular proteolysis', Pflugers Arch. Vol. 447, pp. $776-779$.

25. Mackenzie, B. and Erickson, J.D. (2004), 'Sodium-coupled neutral amino acid (System N/A) transporters of the SLC38 gene family', Pflugers Arch. Vol. 447, pp. 784-795.

26. Bodoy, S., Martin, L., Zorzano, A., Palacin, M., Estevez, R. and Bertran, J. (2005), 'Identification of LAT4, a novel amino acid transporter with system L activity', J. Biol. Chem. Vol. 280, pp. 12002-12011. 
27. Simpson, I.A., Dwyer, D., Malide, D., Moley, K.H., Travis, A. and Vannucci, S.J. (2008), "The facilitative glucose transporter GLUT3: 20 years of distinction', Am. J. Physiol. Endocrinol. Metab. Vol. 295, pp. E242-E253.

28. Wright, E.M., Hirayama, B.A. and Loo, D.F. (2007), 'Active sugar transport in health and disease', J. Intern. Med. Vol. 261, pp. 32-43.

29. Bartoloni, L. and Antonarakis, S.E. (2004), 'The human sugarphosphate/phosphate exchanger family SLC37', Pflugers Arch. Vol. 447, pp. $780-783$.

30. Gregory, S.G., Barlow, K.F, McLay, K.E. et al. (2006), 'The DNA sequence and biological annotation of human chromosome 1', Nature Vol. 441, pp. 315-321

31. Fernandez, L.P., Milne, R.L., Pita, G. et al. (2008), 'SLC45A2: $A$ novel malignant melanoma-associated gene', Hum. Mutat. Vol. 29, pp. 1161-1167.

32. Helgeson, B.E., Tomlins, S.A., Shah, N. et al. (2008), 'Characterization of TMPRSS2: ETV5 and SLC45A3: ETV5 gene fusions in prostate cancer', Cancer Res. Vol. 68, pp. 73-80.

33. Strausberg, R.L., Feingold, E.A., Grouse, L.H. et al. (2002), 'Generation and initial analysis of more than 15,000 full-length human and mouse cDNA sequences', Proc. Natl. Acad. Sci. USA Vol. 99, pp. 16899-16903.

34. Geyer, J., Wilke, T. and Petzinger, E. (2006), 'The solute carrier family SLC10: More than a family of bile acid transporters regarding function and phylogenetic relationships', Naunyn Schmiedebergs Arch. Pharmacol. Vol. 372, pp. 413-431.

35. Pajor, A.M. (2006), 'Molecular properties of the SLC13 family of dicarboxylate and sulfate transporters', Pflugers Arch. Vol. 451, pp. 597-605.

36. Halestrap, A.P. and Meredith, D. (2004), 'The SLC16 gene family From monocarboxylate transporters (MCTs) to aromatic amino acid transporters and beyond', Pflugers Arch. Vol. 447, pp. 619-628.

37. Matsumoto, T., Kanamoto, T., Otsuka, M., Omote, H. and Moriyama, Y. (2008), 'Role of glutamate residues in substrate recognition by human MATE1 polyspecific $\mathrm{H}^{+}$/organic cation exporter', Am. J. Physiol. Cell Physiol. Vol. 294, pp. C1074-C1078.

38. Courville, P., Chaloupka, R. and Cellier, M.F. (2006), 'Recent progress in structure-function analyses of NRAMP proton-dependent metal-ion transporters', Biochem. Cell Biol. Vol. 84, pp. 960-978.

39. Palmiter, R.D. and Huang, L. (2004), 'Efflux and compartmentalization of zinc by members of the SLC30 family of solute carriers', Pflugers Arch. Vol. 447, pp. 744-751.

40. Ford, D. (2004), 'Intestinal and placental zinc transport pathways', Proc. Nutr. Soc. Vol. 63, pp. 21-29.

41. Petris, M.J. (2004), 'The SLC31 (CTR) copper transporter family', Pflugers Arch. Vol. 447, pp. 752-755.

42. Eide, D.J. (2004), 'The SLC39 family of metal ion transporters', Pflugers Arch. Vol. 447, pp. 796-800

43. Girijashanker, K., He, L., Soleimani, M. et al. (2008), 'Slc39a14 gene encodes ZIP14, a metal/bicarbonate symporter: Similarities to the ZIP8 transporter', Mol. Pharmacol. Vol. 73, pp. 1413-1423.

44. Liu, Z., Li, H., Soleimani, M. et al. (2008), ' $\mathrm{Cd}^{2+}$ versus $\mathrm{Zn}^{2+}$ uptake by the ZIP8 $\mathrm{HCO}_{3}^{-}$-dependent symporter: Kinetics, electrogenicity and trafficking', Biochem. Biophys. Res. Commun. Vol. 365, pp. 814-820.

45. McKie, A.T. and Barlow, D.J. (2004), 'The SLC40 basolateral iron transporter family (IREG1/ferroportin/MTP1)', Pflugers Arch. Vol. 447, pp. $801-806$.

46. Maguire, M.E. (2006), 'Magnesium transporters: Properties, regulation and structure', Front. Biosci. Vol. 11, pp. 3149-3163.

47. Christie, D.L. (2007), 'Functional insights into the creatine transporter', Subcell. Biochem. Vol. 46, pp. 99-118.

48. Henry, L.K., Meiler, J. and Blakely, R.D. (2007), 'Bound to be different: Neurotransmitter transporters meet their bacterial cousins', Mol. Interv. Vol. 7, pp. 306-309.

49. Shayakul, C. and Hediger, M.A. (2004), 'The SLC14 gene family of urea transporters', Pflugers Arch. Vol. 447, pp. 603-609.

50. Eiden, L.E., Schafer, M.K., Weihe, E. and Schutz, B. (2004), 'The vesicular amine transporter family (SLC18): Amine/proton antiporters required for vesicular accumulation and regulated exocytotic secretion of monoamines and acetylcholine', Pflugers Arch. Vol. 447, pp. 636-640

51. Nigam, S.K., Bush, K.T. and Bhatnagar, V. (2007), 'Drug and toxicant handling by the OAT organic anion transporters in the kidney and other tissues', Nat. Clin. Pract. Nephrol. Vol. 3, pp. 443-448.

52. Nakhoul, N.L., Dejong, H., Abdulnour-Nakhoul, S.M., Boulpaep, E.L., Hering-Smith, K. and Hamm, L.L. (2005), 'Characteristics of renal RHBG as an $\mathrm{NH}_{4}^{+}$transporter', Am. J. Physiol. Renal Physiol. Vol. 288, pp. F170-F181.

53. O'Regan, S., Traiffort, E., Ruat, M., Cha, N., Compaore, D. and Meunier, F.M. (2000), 'An electric lobe suppressor for a yeast choline transport mutation belongs to a new family of transporter-like proteins', Proc. Natl. Acad. Sci. USA Vol. 97, pp. 1835-1840.

54. Ganapathy, V., Smith, S.B. and Prasad, P.D. (2004), 'SLC19: The folate/ thiamine transporter family', Pflugers Arch. Vol. 447, pp. 641-646.

55. Takanaga, H., Mackenzie, B. and Hediger, M.A. (2004), 'Sodium-dependent ascorbic acid transporter family SLC23', Pflugers Arch. Vol. 447, pp. 677-682.

56. Hirabayashi, Y., Kanamori, A., Nomura, K.H. and Nomura, K. (2004), 'The acetyl-CoA transporter family SLC33', Pflugers Arch. Vol. 447, pp. $760-762$

57. Min, S.H., Oh, S.Y., Karp, G.I., Poncz, M., Zhao, R. and Goldman, I.D. (2008), 'The clinical course and genetic defect in the SLC46A1 gene in a 27-year-old woman with hereditary folate malabsorption', J. Pediatr. Vol. 153 , pp. $435-437$.

58. Obermann, H., Wingbermuhle, A., Munz, S. and Kirchhoff, C. (2003), 'A putative 12-transmembrane domain cotransporter associated with apical membranes of the epididymal duct', J. Androl. Vol. 24, pp. 542-556.

59. Ota, T., Suzuki, Y., Nishikawa, T. et al. (2004), 'Complete sequencing and characterization of 21,243 full-length human cDNAs', Nat. Genet. Vol. 36, pp. 40-45.

60. Pastor-Anglada, M., Cano-Soldado, P., Errasti-Murugarren, E. and Casado, FJ. (2008), 'SLC28 genes and concentrative nucleoside transporter (CNT) proteins', Xenobiotica Vol. 38, pp. 972-994.

61. Molina-Arcas, M., Trigueros-Motos, L., Casado, FJ. and Pastor-Anglada, M. (2008), 'Physiological and pharmacological roles of nucleoside transporter proteins', Nucleosides Nucleotides Nucleic Acids Vol. 27, pp. 769-778.

62. Ishida, N. and Kawakita, M. (2004), 'Molecular physiology and pathology of the nucleotide sugar transporter family (SLC35)', Pflugers Arch. Vol. 447, pp. $768-775$.

63. Stahl, A. (2004), 'A current review of fatty acid transport proteins (SLC27)', Pflugers Arch. Vol. 447, pp. 722-727.

64. Hagenbuch, B. and Gui, C. (2008), 'Xenobiotic transporters of the human organic anion transporting polypeptides (OATP) family', Xenobiotica Vol. 38, pp. 778-801.

65. Lu, R., Kanai, N., Bao, Y. and Schuster, V.L. (1996), 'Cloning, in vitro expression, and tissue distribution of a human prostaglandin transporter cDNA (hPGT)', J. Clin. Invest. Vol. 98, pp. 1142-1149.

66. Ugele, B., St-Pierre, M.V., Pihusch, M., Bahn, A. and Hantschmann, P. (2003), 'Characterization and identification of steroid sulfate transporters of human placenta', Am. J. Physiol. Endocrinol. Metab. Vol. 284, pp. E390-E398

67. Hagenbuch, B. (2007), 'Cellular entry of thyroid hormones by organic anion transporting polypeptides', Best Pract. Res Clin. Endocrinol. Metab. Vol. 21, pp. 209-221.

68. Palmieri, F. (2004), 'The mitochondrial transporter family (SLC25): Physiological and pathological implications', Pflugers Arch. Vol. 447, pp. $689-709$.

69. Klingenspor, M., Fromme, T., Hughes, D.A., Jr et al. (2008), 'An ancient look at UCP1', Biochim. Biophys. Acta Vol. 1777, pp. 637-641.

70. Graier, W.F., Trenker, M. and Malli, R. (2008), 'Mitochondrial $\mathrm{Ca}^{2+}$, the secret behind the function of uncoupling proteins-2 and -3?', Cell Calcium Vol. 44, pp. 36-50.

71. Affourtit, C. and Brand, M.D. (2008), 'On the role of uncoupling protein-2 in pancreatic beta cells', Biochim. Biophys. Acta Vol. 1777, pp. $973-979$ 